\title{
PRODUCTIVITY AND GROWTH IN COWPEA INOCULATED WITH RHIZOBIA UNDER DIFFERENT LIGHT ENVIRONMENTS
}

Andreza de Jesus CORREIA ${ }^{1}$ (i), Rafaela Simão Abrahão NÓBREGA ${ }^{2}$ (D) Amanda Santos OLIVEIRA $^{3}$ (i), Welly Sacramento SANTANA ${ }^{3}$ (D) , Caliane da Silva BRAULIO ${ }^{4}$ (D) , Marluce Santana de OLIVEIRA ${ }^{3}$ iD, Cheila Bonati do Carmo de SOUSA ${ }^{1}$ (D) , Anacleto Ranulfo dos SANTOS ${ }^{2}$ (D)

\footnotetext{
${ }^{1}$ Postgraduate Program in Soils and Ecosystem Quality, Federal University of Recôncavo da Bahia, Cruz das Almas, Bahia, Brazil.

${ }^{2}$ Center of Agricultural, Environmental and Biological Sciences, Federal University of Recôncavo da Bahia, Cruz das Almas, Bahia, Brazil.

${ }^{3}$ Agroecology Technology, Federal University of Recôncavo da Bahia, Cruz das Almas, Bahia, Brazil.

4 Postgraduate Program in Agrarian Sciences, Federal University of Recôncavo da Bahia, Cruz das Almas, Bahia, Brazil.
}

Corresponding author:

Rafaela Simão Abrahão Nóbrega

Email: rafaela.nobrega@ufrb.edu.br

How to cite: CORREIA, A.J., et al. Productivity and growth in cowpea inoculated with rhizobia under different light environments. Bioscience Journal. 2021, 37, e37057. https://doi.org/10.14393/BJ-v37n0a2021-51542

\begin{abstract}
The objective of this work was to verify the influence of light environments combined with rhizobia inoculation on cowpea growth and productivity. A completely random design was used in a $4 \times 4$ factorial scheme, with four light environments, four nitrogen sources and eight replicates in split plot parcels. Light environments were set by means of photo-conversion and thermo-conversion nettings (Aluminet ${ }^{\circledR}$, red net and black net) and control treatment without shading (full sun). Nitrogen sources were constituted by the strains INPA 03-11B - SEMIA 6462 (Bradyrhizobium elkanni) and UFLA 03-84 - SEMIA 6461 (Bradyrhizobium viridifuturi), and two control treatments: with $70 \mathrm{~kg} \mathrm{ha}^{-1}$ of mineral nitrogen and without $\mathrm{N}$. Plant height, indices of chlorophyll $a, b$ and total chlorophill, the number of leaves, number of nodules, dry matter of nodules, dry matter of the aerial portion, dry matter of roots and total dry matter, relative efficiency, gathering of nitrogen in the aerial portion, number, length and matter of pods per plant and dry matter of 100 grains, were evaluated. . There was interaction between light conditions and nitrogen sources for the number of nodules. Individual effect was observed in all other variables. Strain INPA 03-11B was able to promote higher nodulation in cowpea plants in light environments under full sun and Aluminet and the strain UFLA 03-84 only under full sun conditions. However, the efficiency of diazotrophic bacteria to promote vegetative growth, nitrogen gathering and production was not influenced by different light environments. Thus, full sun cultivation is recommended, independently of the nitrogen source used.
\end{abstract}

Keywords: Biological Nitrogen Fixation. Shading. Vigna unguiculata L. Walp.

\section{Introduction}

Plant cultivation technologies may be improved for production in small and urban areas, primarily when aiming production of organic crops and increasing the accessibility to better quality foods for the population.

One of the technologies available nowadays when considering the production of plants in small areas consists in the use of nets. These nets modify the quality and quantity of incident light and interfere, directly or indirectly, in the photosynthetic apparatus of plants (Lacerda et al. 2010; Santos et al. 2011; Taiz and Zeiger 2013). As a result, plants may display modifications in foliar anatomy (Taiz and Zeiger 2013). 
Nets may produce microclimatic variations, changing the metabolism of plants cultivated under such light environments (Lima et al. 2010). Thus, indices of chlorophyll, the number of leaves, foliar area, and the dry matter of the aerial portion of several species such as bean, corn, coffee and tomato, among others, may increase (Lacerda et al. 2010; Henrique et al. 2011; Santos et al. 2011; Ilic et al. 2012; Hirata and Hirata 2015). In cowpea higher indices of chlorophyll were obtained when plants were submitted to shading environments, however, the highest mean value for dry matter of the aerial portion was obtained in plants under full sun environments (Santos et al. 2011).

Cowpea is an important protein source, it also contains a valuable content of fibers and vitamins, has reduced lipid content and high proportion of unsaturated fatty acids, thus, it is well suited for consumers in demand for healthier nutrition and lifestyle (Frota, Soares and Arêas 2008). Light modifying environment nets may be used by farmers in green belts, big cities and municipalities aiming to produce organic vegetables maximizing their production, mainly when considering production in small areas. Thus, such harvests may be commercialized in local markets or even use for familiar consumption during the whole year, due to the benefits provided by these nets, such as protection against radiation, excessive rain, plant diseases and pests.

Cowpea is extensively studied when concerning the benefits of Biological Nitrogen Fixation (BNF) and its potential to increase crop production (Costa et al. 2016; Lira Júnior et al. 2017; Marinho et al. 2017; Batista et al. 2017; Xavier et al. 2017). There are already for strains recommended and authorized by the Ministry of Agriculture, Livestock and Supply (MAPA) for cowpea in Brazil: UFLA 03 84 (SEMIA 6461), INPA 03-11B (SEMIA 6462), BR 3267 (SEMIA 6463) and BR 3262 (SEMIA 6464) (MAPA 2011). Studies show that strains UFLA 03-84 and INPA 03-11B significantly contribute in cowpea production, when compared to mineral nitrogen and non-inoculated crops, increasing the production of plant dry matter, production and contents of nitrogen in the aerial portion and the grains (Farias et al. 2016a; Farias et al. 2016b; Batista et al. 2017; Marinho et al. 2017).

The quality of light affects cowpea growth promoting higher photosynthesis efficiency (Santos et al. 2011) and may also influence the efficiency of diazotrophic bacteria. The quality and quantity of light may stimulate photosynthesis, therefore, an increment in the dry matter of the aerial portion and grain production is expected due to the increase in photoassimilate's synthesis (Arruda, Lopes and Bacarin 2001; Kerbauy 2019). We hypothesize the efficiency of cowpea inoculated with rhizobia may be maximized by using photo-conversion and thermo-conversion nets. The objective of this study was to verify the influence of light environments combined with rhizobia inoculation on cowpea growth and productivity.

\section{Material and Methods}

The experiment was performed in greenhouse at the Federal University of Recôncavo da Bahia (UFRB), at the Agrarian, Biological and Environmental Sciences campus, in the county of Cruz das Almas Bahia, Brazil $\left(12^{\circ} 40^{\prime} 19^{\prime \prime} \mathrm{S}\right.$ e $\left.39^{\circ} 06^{\prime} 22^{\prime \prime} \mathrm{W}\right)$. During the experimental period the daily mean temperature, measured at noon (12:00), was of $33 \stackrel{\circ}{\circ}$.

The soil was collected at the Bahia Federal Institute of Education, Science and Technology, in the

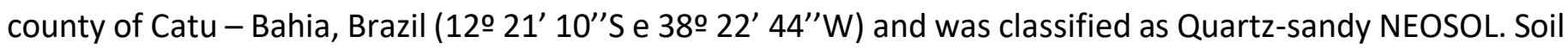
texture was determined as sandy loam with 853,118 and $30 \mathrm{~g} \mathrm{~kg}^{-1}$ total sand, silt and clay, with the following attributes (evaluated at a 0 to $0.2 \mathrm{~m}$ depth): $\mathrm{pH}\left(\mathrm{H}_{2} \mathrm{O}\right)=5.15 ; \mathrm{M} . \mathrm{O}=1.04 \mathrm{~g} \mathrm{dm}^{-3} ; \mathrm{P}=6.40 \mathrm{mg} \mathrm{dm}^{-3} ; \mathrm{K}=14.00$ $\mathrm{mg} \mathrm{dm}{ }^{-3} ; \mathrm{Na}=0.0 \mathrm{cmol}_{\mathrm{c}} \mathrm{dm}^{-3} ; \mathrm{Ca}=1.50 \mathrm{cmol}_{\mathrm{c}} \mathrm{dm}^{-3} ; \mathrm{Mg}=0.34 \mathrm{cmol}_{\mathrm{c}} \mathrm{dm}^{-3} ; \mathrm{H}+\mathrm{Al}=2.2 \mathrm{cmol}_{\mathrm{c}} \mathrm{dm}^{-3} ; \mathrm{SB}=$ $1.88 \mathrm{cmol}_{\mathrm{C}} \mathrm{dm}^{-3} ; \mathrm{CEC}=3.08 \mathrm{cmol}_{\mathrm{c}} \mathrm{dm}^{-3}$ and $\mathrm{V}=46.1 \% ; \mathrm{S}=1.00 \mathrm{mg} \mathrm{dm}^{-3} ; \mathrm{B}=0.17 \mathrm{mg} \mathrm{dm}^{-3} ; \mathrm{Cu}=0.89 \mathrm{mg} \mathrm{dm}^{-}$ 3; $\mathrm{Mn}=13.7 \mathrm{mg} \mathrm{dm}^{-3} ; \mathrm{Fe}=114.5 \mathrm{mg} \mathrm{dm}^{-3} ; \mathrm{Zn}=3.14 \mathrm{mg} \mathrm{dm}^{-3}$.

The soil was sieved through a $4 \mathrm{~mm}$ mesh and conditioned in $3 \mathrm{~L}$ plastic pots. Then, soil samples were incubated with $0.119 \mathrm{~g} \mathrm{dm}^{-3}$ of limestone. To complement soil fertilization and according to the results from the soil analysis, $0.105 \mathrm{~g} \mathrm{dm}^{-3} \mathrm{P}_{2} \mathrm{O}_{5}\left(70 \mathrm{~kg} \mathrm{ha}^{-1}\right)$ used as simple superphosphate and $0.078 \mathrm{~g} \mathrm{dm}^{-3} \mathrm{~K}_{2} \mathrm{O}$ (30 kg $\mathrm{ha}^{-1}$ ) used as potassium chloride, were applied.

A completely randomized design was used in the experiment in a $4 \times 4$ factorial scheme with four light environments and four nitrogen sources, with eight replicates in split plot parcels. Parcels were constituted of light environments and split parcels were constituted by nitrogen sources. 
Light environments were constituted by photo-converting and thermo-converting nets with $50 \%$ shading: ChromatiNet Aluminet ${ }^{\circledR}$, ChromatiNet Red $^{\circledR}$, black net (sombrite) and control without shading (full sun).

ChromatiNet Aluminet ${ }^{\circledR}$ modifies radiation properties, increasing its reflection and allowing temperature control. ChromatiNet $\operatorname{Red}^{\circledR}$ adds wave lengths in the spectral range of red and far red, with transmittance for wavelengths higher than $590 \mathrm{~nm}$ and low peak around $400 \mathrm{~nm}$ (violet) reducing blue, yellow and green wavelengths (Polysack 2019). Black net is considered neutral, it acts reducing the incidence of radiation without alteration of the spectral light quality. Nets were combined with four nitrogen sources, rhizobium strains INPA 03-11B - SEMIA 6462 (Bradyrhizobium elkanii) and UFLA 03-84 - SEMIA 6461 (Bradyrhizobium viridifuturi), control treatment with $105.3 \mathrm{dm}^{-3}$ mineral nitrogen (70 kg ha-1) (Costa et al. 2019) applied as urea and control treatment without any $\mathrm{N}$ source.

The inoculants were purchased from Embrapa Agrobiology, in peat and minimal rhizobium concentration of $10^{8}$ cells $\mathrm{g}^{-1}$ of inoculant. Inoculation of seeds was performed at a proportion of $250 \mathrm{~g}$ of inoculant for $50 \mathrm{~kg}$ of seeds.

Seeds were purchased in the market in the county of Cruz das Almas - BA, cultivar EPACE 10: medium cycle, medium branch size, indeterminate growth habit and brown color grains, drought tolerant, adaptable and resistant against virus (Andrade Júnior et al. 2002). Seeds were surface disinfected with ethanol $98 \%$ (30 s), sodium hypochlorite $1 \%(2 \mathrm{~m})$ and three washes with autoclaved distilled water (Costa et al. 2016).

Seeding was achieved with five seeds per pot. After 15 days (stage V2), thinning was completed leaving only one per pot and applying nitrogen in the corresponding treatment. Plants were irrigated according to the soil moisture, obtained by the curve of soil water retention, aiming to preserve $60 \%$ of the field capacity. Estimation of water reposition was achieved by mattering pots to calculate the evapotranspirated quantity.

Fifty days after seeding, during blooming period (stage R1), four plants from each treatment were evaluated regarding: $a, b$ and total photosynthetic pigments (CLA, CLB and CLT) using an electronic chlorophyll meter (clorofiLOG CFL 1030 Falker), height (H), and number of leaves (NL). Later, plants were collected, and the number of nodules (NN) was evaluated. Then, plants were conditioned in paper bags and dried in a forced air oven at 60 $\mathrm{C}$ for $72 \mathrm{~h}$. After this period the dry matter of the aerial portion, roots, and total dry matter (DMAP, DMR and DMT), dry matter of nodules (DMN) and the relative efficiency (RE), were evaluated. The RE was calculated by the relation of the dry matter of the aerial portion of the inoculated control and the dry matter of the aerial portion of the control with mineral $\mathrm{N}$, multiplied by 100 . The aerial portion was crushed in a Willey mill. Four $0.1 \mathrm{~g}$ samples from each treatment were digested in $\mathrm{H}_{2} \mathrm{SO}_{4}+\mathrm{H}_{2} \mathrm{O}_{2}$ and the content of nitrogen was determined by the phenol-hypochlorite method (Weatherburn 1967). The gathering of $\mathrm{N}$ in the aerial portion (GNAP) was determined by the relation: $\operatorname{DMAP}(\mathrm{g})$ * $(\%$ de $\mathrm{N}) / 100$.

The second evaluation was accomplished during harvest, 90 days after seeding (stage R5). Pods were collected and their number, length and the matter of pods per plant (NPP, LPP and (MPP), were evaluated. One hundred seeds were dried in forced air oven at $105 \% \mathrm{C}$, and humidity fixed to $13 \%$, in order to determine the matter of 100 grains (M100G).

Data was submitted to analysis of variance ant the $\mathrm{F}$ test at $5 \%$ probability. Means were compared by the Tukey test at $5 \%$ probability. The variables analyzed were used to calculate the correlation coefficients of Spearman and their significances were tested by the $t$ test of Student at $1 \%$ and $5 \%$ probability, using the statistical software " $R$ " (R development core team 2018). Data of NN and MNS were transformed to $(X+0.5)$ 0.5 .

\section{Results and Discussion}

Light environments and nitrogen sources influenced $(p<0.05)$ growth and production of cowpea. There was no interaction of light environments with nitrogen sources for the indices of chlorophyll $a, b$ and total chlorophyll (CLA, CLB and CLT), number of leaves (NL), plant height $(H)$, matter of dry nodules (DMN), matter of the dry aerial portion, dry roots and total dry matter (MDAP, DMR and DMT), gathering of nitrogen in the aerial portion (GNAP), relative efficiency (RE), number, length and matter of pod per plant (NPP, LPP and MPP) and matter of 100 grains (M100G). 
Individual effect of light environments on chlorophyll indices $a, b$ and total (CLA, CLB and CLT) and variables $\mathrm{H}, \mathrm{DMN}, \mathrm{DMAP}, \mathrm{DMR}, \mathrm{DMT}$ and GNAP in cowpea plants was evidenced (Table 1).

Table 1. Cowpea (Vigna unguiculata L. Walp) growth at blooming cultivar EPACE 10, under different light environments.

\begin{tabular}{|c|c|c|c|c|c|c|c|c|c|c|}
\hline \multirow{2}{*}{$\begin{array}{l}\text { Light } \\
\text { Environment }\end{array}$} & \multicolumn{3}{|c|}{ Chlorophyll } & $\mathrm{NL}$ & $\mathrm{H}$ & DMN & DMAP & DMR & DMT & \multirow{2}{*}{ 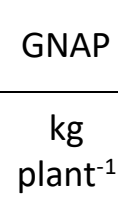 } \\
\hline & $a$ & $b$ & total & plant $^{-1}$ & $\mathrm{~cm}_{\text {plant }}{ }^{-1}$ & --- & -----g pl & $\mathrm{nt}^{-1}--$ & --- & \\
\hline Aluminet & $40.93^{a}$ & $15.70^{\mathrm{a}}$ & $56.63^{a}$ & $16.16^{a}$ & $44.89^{b}$ & $0.91^{a}$ & $5.31^{\mathrm{a}}$ & $0.69^{a}$ & $6.00^{a}$ & $0.16^{a}$ \\
\hline Red net & $36.64^{\mathrm{ab}}$ & $11.61^{b}$ & $48.25^{b c}$ & $15.53^{\mathrm{a}}$ & $49.08^{a}$ & $0.89^{a b}$ & $4.44^{b}$ & $0.69^{a}$ & $5.13^{b}$ & $0.13^{b}$ \\
\hline Black net & $40.78^{a}$ & $14.43^{\mathrm{ab}}$ & $55.21^{\mathrm{ab}}$ & $15.06^{\mathrm{a}}$ & $46.68^{b}$ & $0.88^{b c}$ & $4.10^{b}$ & $0.69^{a}$ & $4.79^{b}$ & $0.12^{\mathrm{b}}$ \\
\hline Full sun & $33.08^{b}$ & $11.57^{b}$ & $44.65^{c}$ & $12.69^{b}$ & $40.20^{c}$ & $0.87^{c}$ & $5.11^{\mathrm{a}}$ & $0.69^{\mathrm{a}}$ & $5.80^{\mathrm{a}}$ & $0.15^{a}$ \\
\hline CV (\%) & 18.08 & 40.67 & 23.66 & 15.03 & 6.58 & 0.71 & 12.13 & 4.25 & 10.7 & 13.65 \\
\hline
\end{tabular}

*Means followed by the same letter within the column are not statistical different by the Tukey test at $5 \%$ probability. CLA, CLB and $\mathrm{CLT}=$ indices of chlorophyll $a, b$ and total, $\mathrm{NL}=$ number of leaves, $\mathrm{H}=$ plant height, $\mathrm{DMN}=$ dry matter of nodules, DMAP, DMR and $\mathrm{DMT}=$ dry matter of the aerial portion, the roots and total dry matter, GNAP= gathering of nitrogen in the aerial portion.

Light and temperature are restriction factors for the cultivation of vegetal species in different soil and climate conditions (Hirata and Hirata 2015). Plants cultivated in environments under Aluminet, red and black nets did not differ $(p>0.05)$ regarding CLA. Aluminet and black nets favored higher means of CLB and CLT (Table 1). Plants cultivated in environments under nets showed higher values for CLA, CLB and CLT when compared to plants cultivated at full sun. These results agree with those observed by Santos et al. (2011), when cultivating cowpea at full sun and artificial environment ( $50 \%$ luminosity). Cowpea plants shows plasticity when submitted to low luminosity conditions and are capable to increase the indices of chlorophyll, plant height and foliar area to acclimatize to the environment (Lacerda et al. 2010; Santos et al. 2011). The cowpea cultivar in the present study was able to modify its photosystem regarding the quantity of pigments and relative composition of CLA, CLB and CLT.

Higher indices of chlorophyll (chlorophyll $a, b$ and total) obtained in plants cultivated under artificial environment did not reflect, in a significant manner, the dry matter production from these plants. Therefore, photosynthetic pigments are not directly responsible by the accretion of dry matter over time, as can be demonstrated through the means obtained DMAP, DMR and DMT. Cultivation of cowpea under shading promotes the increase of chlorophyll indices and decrease of matter of the aerial portion, results like those registered by different authors (Lacerda et al. 2010; Santos et al. 2011; Paulus et al. 2016).

In environments under Aluminet, red and black nets, plants showed means statistically equal and differed only from the control treatment under full sun, regarding NL (Table 1). Plants cultivated in light environment under red net showed higher mean for $\mathrm{H}$. The increment of mean values for plant growth observed in plants cultivated under red net may be related to the plant adaptation to the conditions proportioned by the light quality, reduction of temperature and consequently, the reduction of water losses by evaporation.

DMN was higher when plants were cultivated in environments under Aluminet and red nets, surpassing values observed under full sun (Table 1). The increment of chlorophyll indices and higher photosynthetic efficiency promoted by the light environments under Aluminet and red nets favored DMN, which may contribute for a higher efficiency of the BNF.

Light environments under Aluminet and full sun promoted the higher means for DMAP. Higher photosynthetic efficiency under these environments may have enhanced DMAP. Light environments did not interfere on DMR ( $p>0.05)$. Plants cultivated in environments under Aluminet and full sun showed higher means for DMT and differed from treatments with black and red nets (Table 1). Although the environment under red net promoted higher $\mathrm{H}$, etiolation reduced DMAP and DMT, this effect can be observed when comparing plant height under red net with all other treatments. As all light treatments have shading of $50 \%$ and black net is used to isolate the effect of shading, cowpea plant growth was negatively influenced by the quality of light provided by the red net. The reduction of these growth factors may jeopardize the crop production. 
Plants cultivated under Aluminet showed similar results to plants cultivated under full sun for DMAP, DMT and GNAP. The increase of diffuse light transmission promoted by the shading mesh Aluminet, increased plant growth when compared to red and black nets. Physiological growth in plants may be optimized by identifying an adequate interval of shading and quality of spectral light (llic et al. 2012). Light controls the gathering of dry matter in the plant, contributing for growth, and plasticity is related with adaptation to different conditions of radiation, leading to changes in the photosynthetic mechanism with the objective of render efficient gathering of dry matter and contribute to vegetative growth (Lacerda et al. 2010; Santos et al. 2011).

Phytochromes vigorously absorb light in the light range of red and far-red and less intensively in the range of blue light (Mathews 2010). Therefore, shading promotes higher proportion of blue far-red light, which is converted in red, inducing the plant to preserve a major part of its resources for growth in height (Taiz and Zeiger 2013). Plants cultivated under red nets have an enhanced $\mathrm{CO}_{2}$ assimilation apparatus, therefore, leaves may show higher viability for red radiation, once they have higher transmittance for wavelengths of $590 \mathrm{~nm}$ (red light), which makes them more skillful for the photochemical stage of photosynthesis (Henrique et al. 2011).

The results observed for $\mathrm{H}$ and DMAP are related with the adaptation strategy of plants which promotes higher light absorption and contributes to the increase of photosynthetic efficiency and higher carbon utilization, due to a higher foliar area to absorb luminous energy (Taiz and Zeiger 2013). The thermoreflector net Aluminet enables to control the temperature difference between day and night, preserving plants from excessive solar radiation and keeping heat in the interior environment during the winter period (Paulus et al. 2016). In such manner, climatic conditions and light quality provided by the Aluminet net were more efficient to promote dry mas of the aerial portion. Aluminet net may be recommended for cowpea cultivation by small farmers aiming better plant growth and production in non-favorable seasons.

GNAP was higher in plants cultivated under Aluminet and full sun, which differentiate from plants under red and black nets. The presence of nitrogen may stimulate the increment of biomass per area, foliar area, and photosynthetic rate (Alves et al. 2018). In such context, the availability of nitrogen favors cowpea growth when cultivated in light environments under Aluminet and full sun.

Physiological development in the vegetative growing stage is influenced by environmental factors such as the quality, quantity, and exposure period to radiation, which promotes anatomical and morphological modifications on leaves (Souza et al. 2014). In this way, morphological changes of cultivated plants in light environments under black and red nets do not provide conditions for plants, once despite the increment in the mean valued for $\mathrm{H}$ and chlorophyll indices, those environments reduced DMAP and DMT, which may compromise cowpea growth and production.

There was significant difference $(p<0.05)$, regarding the nitrogen sources for, DMR, DMT, GNAP and RE (Table 2).

There was no difference $(p<0.05)$ for chlorophyll indices in relation to the nitrogen sources. $\mathrm{H}$ increased with inoculation and mineral nitrogen fertilization. Mean values for DMN were superior in treatments with inoculation and inferior in control treatments with and without mineral $\mathrm{N}$ and did not differ among themselves (Table 2). As the dry matter of nodules increased the DMAP also increased when plants were inoculated with the strain INPA 03-11B.

Table 2. Growth of cowpea plants (Vigna unguiculata L. Walp) cultivar EPACE 10, at blooming, inoculated with diazotrophic bacteria.

\begin{tabular}{|c|c|c|c|c|c|c|c|c|c|}
\hline \multirow[b]{2}{*}{ Nitrogen sources } & \multicolumn{2}{|c|}{ Chlorophyll } & \multirow{2}{*}{$\frac{\mathrm{H}}{\mathrm{cm}_{\substack{1 \\
\text { plant }}}}$} & \multirow[t]{2}{*}{ DMN } & DMAP & DMR & \multirow[t]{2}{*}{ DMT } & \multirow{2}{*}{$\begin{array}{c}\text { GNAP } \\
\text { kg } \\
\text { plant }^{-1}\end{array}$} & \multirow{2}{*}{$\begin{array}{l}\mathrm{RE} \\
\%\end{array}$} \\
\hline & $a$ & total & & & -----g pl & $t^{-1}$ & & & \\
\hline INPA 03-11B & $40.02^{\mathrm{a}}$ & $54.96^{a}$ & $46.16^{a}$ & $0.93^{\mathrm{a}}$ & $5.73^{a}$ & $0.92^{\mathrm{a}}$ & $6.65^{a}$ & $0.18^{a}$ & $121.98^{\circ}$ \\
\hline UFLA 03-84 & $36.99^{a}$ & $49.39^{a}$ & $45.91^{\mathrm{a}}$ & $0.92^{\mathrm{a}}$ & $4.68^{b}$ & $0.71^{\mathrm{b}}$ & $5.39^{b}$ & $0.14^{b}$ & $99.91^{b}$ \\
\hline With N & $37.45^{a}$ & $50.24^{a}$ & $45.16^{a}$ & $0.89^{b}$ & $4.77^{b}$ & $0.69^{b}$ & $5.46^{b}$ & $0.15^{b}$ & $100.00^{\mathrm{b}}$ \\
\hline Without N & $36.97^{a}$ & $50.18^{\mathrm{a}}$ & $43.61^{b}$ & $0.87^{\mathrm{b}}$ & $3.78^{c}$ & $0.43^{c}$ & $4.21^{c}$ & $0.08^{c}$ & $81.43^{c}$ \\
\hline CV (\%) & CV (\%) & 12.68 & 16.96 & 5.06 & 2.11 & 12.62 & 5.91 & 11.21 & 13.57 \\
\hline
\end{tabular}


*Means followed by the same letter are not statistically different by the Tukey test at $5 \%$ probability. With $\mathrm{N}=70 \mathrm{~kg}$ ha ${ }^{-1} \mathrm{mineral}$ $\mathrm{N}$, Without $\mathrm{N}=$ without inoculation and without $\mathrm{N}$ fertilization. CLA, CLB and CLT= indices of chlorophyll $a, b$ and total, $\mathrm{H}=$ plant height, $\mathrm{DMN}=$ dry matter of nodules, DMAP, DMR and DMT= dry matter of the aerial portion, roots and total, GNAP= gathering of nitrogen in the aerial portion, $\mathrm{RE}=$ relative efficiency.

The strain INPA 03-11B showed higher DMAP mean and differed from all other $\mathrm{N}$ sources. Plants which did not received any $N$ source showed lower means, which may signal low availability of $N$ in the soil. Strain INPA 03-11B also excelled concerning DMR and DMT, and was superior to the strain UFLA 03-84 and the control treatment with $\mathrm{N}$ (Table 2). The results obtained in the present work demonstrate the potential of bacterial strains tested to gather biomass in cowpea. The increment in DMAP may be related with the higher gathering of nitrogen in leaves, once this may increase the rate of chlorophylls, leaf area and photosynthesis. Higher plant growth may also be attributed to the synthesis of phytohormones by bacteria, such as auxins, gibberellins and cytokinins, which regulate and participate in growing, development and cellular division processes in the plant (Taiz and Zeiger 2013; Gopalakrishnan et al. 2015).

The highest mean values for $\mathrm{H}, \mathrm{DMN}$, DMAP, DMR and DMT observed whit the inoculation of strain INPA 03-11B evidences the efficiency of BNF to promote plant growth and provide the nitrogen required by cowpea plants. This effect may also be observed in the increment of GNAP which was stimulated by the inoculation of strain INPA 03-11B, showing mean values higher than the strain UFLA 03-84 and the control treatment with $\mathrm{N}$. Plants which did not received $\mathrm{N}$ showed lower mean values for GNAP (Table 2) Inoculation provides the required nitrogen for cowpea and favors better vegetative growth being able to substitute, partially or completely, nitrogen fertilization.

RE was improved by the strain INPA 03-11B, showing better performance when compared to strain UFLA 03-84 and the control with N (Table 2). The control treatment without $\mathrm{N}$ showed lower mean values which may indicate low efficiency of native bacteria and nitrogen deficiency in the soil. In an experiment performed in the southwest of the State of Piauí, in field conditions, Costa et al. (2014) verified a similar effect between those two strains when inoculated in cowpea.

Cowpea may be used as green fertilizer to supply nitrogen to the soil, therefore, the increment of DMAP by bacteria strains represents an advantage over other $\mathrm{N}$ sources (Farias et al. 2016a). Inoculation promoted better cowpea growth, as previously observed in the State of Maranhão, Brazil, while studying species of diazotrophic bacteria in field conditions which promoted higher mean values for DMAP, GNAP and RE (Farias et al. 2016b). This evidences the availability of nitrogen by diazotrophic bacteria, and the benefits promoted in cowpea by inoculation.

Strain INPA 03-11B showed efficiency fixing nitrogen, producing matter equivalent to $21 \%$ more of the dry matter of aerial portion produced by the control treatment with mineral N. Similar behavior was observed concerning the biomass of inoculated cowpea by Costa et al. (2014) and Marinho et al. (2017), in greenhouse conditions and in the field. Supply of nitrogen by the authorized strains was essential for production of dry matter, once the potential to fix nitrogen is associated to the efficiency in supplying $\mathrm{N}$, which may be observed by the relative efficiency and production of matter of the aerial portion.

There was interaction effect $(p<0.05)$ between light environments and nitrogen sources on the number of nodules (NN), in the evaluation performed during blooming (stage R1) (Table 3). The higher mean values for NN were promoted by the strain INPA 03-11B, when cowpea plants were cultivated in light environment under Aluminet and full sun. Strain UFLA 03-84 promoted higher NN when plants were cultivated at full sun (Table 3).

Light environments with red and black nets showed mean values for NN inferior to all other light environments. This shows those wavelengths negatively interfere in the establishment of symbioses between diazotrophic bacteria and cowpea. The higher efficiency of photosynthesis observed by DMAP and produced in environments under Aluminet and full sun promoted higher NN and DMN. The production of photoassimilates due to the higher photosynthetic efficiency in these environments may be contributed to develop nodules and optimize BNF (Arruda, Lopes and Bacarin 2001; Kerbauy 2019). Thus, light environments under Aluminet and full sun comprehend the best environments for increment of number of nodules and the strain INPA 03-11B promotes the higher number of them, when compared to all other nitrogen sources (Table 3 ). 
Table 3. Outcome of the interaction between light environments and nitrogen sources on the number of nodules (NN).

\begin{tabular}{lcccc}
\hline \multirow{2}{*}{ Nitrogen sources } & \multicolumn{4}{c}{ NN (plant ${ }^{-1}$ ) } \\
\cline { 2 - 4 } & \multicolumn{4}{c}{ Light environments } \\
\cline { 2 - 4 } & Aluminet & Red net & Black net & Full sun \\
\hline INPA 03-11B & $23.20^{\mathrm{Aa}}$ & $21.01^{\mathrm{Ba}}$ & $21.14^{\mathrm{Ba}}$ & $23.40^{\mathrm{Aa}}$ \\
UFLA 3-84 & $21.20^{\mathrm{Bb}}$ & $19.67^{\mathrm{Cb}}$ & $19.59^{\mathrm{Cb}}$ & $23.00^{\mathrm{Aa}}$ \\
With N & $19.51^{\mathrm{Bc}}$ & $16.93^{\mathrm{Cc}}$ & $16.93^{\mathrm{Cc}}$ & $22.19^{\mathrm{Ab}}$ \\
Without N & $17.76^{\mathrm{Bd}}$ & $14.53^{\mathrm{Cd}}$ & $15.29^{\mathrm{Cd}}$ & $21.40^{\mathrm{Ac}}$ \\
CV Light environments (\%) & & & 2.17 & \\
CV Nitrogen sources (\%) & & & 2.05 & \\
\hline
\end{tabular}

**Means followed by the same letter within the column are not statistically different by the Tukey test at $5 \%$ probability. With $\mathrm{N}=$ $70 \mathrm{~kg} \mathrm{ha}^{-1}$ mineral $\mathrm{N}$, Without $\mathrm{N}=$ without inoculation and without $\mathrm{N}$.

Analyzing NN data it is possible to infer the soil used in the experiment had native rhizobia which were able to establish symbiosis with cowpea plants, in agreement with previous results observed by Farias et al. (2016b), in a field experiment in the State of Maranhão, Brazil. Being considered as a plant which may establish symbiotic associations with diverse diazotrophic bacterial species, cowpea may associate with nonefficient strains which did not provide the adequate quantities of $\mathrm{N}$. Thus, the results observed in the present work led us to conclude the native rhizobia in the soil used in the experiment are not efficient. To verify the efficiency of rhizobia the DMN and DMAP must be also evaluated, to determine the increment promoted by the strains.

In the second evaluation, during the harvest period (stage R5), light environments and nitrogen sources influenced $(p<0.05)$ cowpea production. No interaction between light environments and $N$ sources was observed for production variables of number, length and matter of pod per plant (NPP, LPP and MPP) and matter of 100 grains (M100G).

A significant effect of light environments was verified for NPP, MPP and M100G. There was no significant effect for LPP. Plants cultivated under full sun showed higher mean values for MPP and M100G, however did not differ $(p<0.05)$ from the environment under Aluminet for means of NPP and M100G. Black net promoted mean values for M100G similar to Aluminet and full sun (Table 4). Light quality provided by the red net influenced negatively in cowpea growth, which may have affected the photosynthetic process and compromised crop production.

As well as it was verified with the results from the vegetative stage of cowpea, the use of red and black nets reduced the mean values for MPP. Regarding the mean value of M100G, Aluminet and black net were similar to the full sun treatment. The similarity between Aluminet and full sun cultivation demonstrates the adaptation capacity of cowpea to different light environments. When cultivating Phaseolus vulgaris $\mathrm{L}$. with $50 \%$ shading, no reduction of MPP was observed whit the increase of shading, when compared to full sun results (Souza et al. 2001). When Phaseolus vulgaris L. was cultivated in shading environment, no difference was observed in pod yield when compared to full sun environment (Heldwein et al. 2010).

Table 4. Production of cowpea (Vigna unguiculata L. Walp) cultivar EPACE 10, cultivated under different light environments.

\begin{tabular}{lcc}
\hline \multirow{2}{*}{ Light environments } & MPP & M100G \\
\cline { 2 - 3 } & & $------------g$ plant ${ }^{-1}---------$ \\
\hline Aluminet & $2.28^{\mathrm{b}}$ & $22.28^{\mathrm{a}}$ \\
Red net & $2.18^{\mathrm{b}}$ & $20.29^{\mathrm{b}}$ \\
Black net & $2.22^{\mathrm{b}}$ & $21.21^{\mathrm{ab}}$ \\
Full sun & $2.85^{\mathrm{a}}$ & $22.19^{\mathrm{a}}$ \\
CV (\%) & 22.95 & 8.15 \\
\hline
\end{tabular}

*Means followed by the same letter within the column are not statistically different by the Tukey test at $5 \%$ probability. MPP= matter of pods per plant, $\mathrm{M} 100 \mathrm{G}=$ matter of 100 grains. 
When cultivated in environments with red and black nets, cowpea plants-initiated flowering with 45 days of cultivation, while plants under Aluminet and full sun initiated flowering with 50 days. However, the anticipated flowering did not provide higher mean values for the production variables analyzed.

Cultivation of cowpea under Aluminet and full sun promoted better growth and production. Morphological changes were observed, attributed to adaptation to adverse conditions, corroborating results observed by Lacerda et al. (2010), while evaluating bean and corn plants in environments with $50 \%$ shading and under full sun, where both plants showed higher mean values for dry matter when cultivated at full sun.

The higher nodulation in plants cultivated under Aluminet and full sun evidences the higher photosynthetic efficiency in these environments, which may have maximized the production of photoassimilates and contributed to a higher NN. The use of Aluminet may be recommended for farmers aiming to produce organic crops, increasing production, and reducing the use of chemicals or even save resources by reducing irrigation necessities. Once Aluminet reduces UV wavelengths and transmit diffuse light promoting increase in photosynthetic activity; it reduces the internal temperature in greenhouses during summer and preserves internal temperature during winter and cooler nights, such microclimatic control and reflection of UV radiation diminishes the incidence of insects and diseases; preserves relative humidity and promotes higher plant absorption and translocation of nutrients (Polysack 2019). Such factors may allow higher cowpea production, reduce production costs, and enable production of organic products.

Nitrogen sources had a significant effect on NPP, LPP, MPP and M100G. The strain INPA 03-11B increased NPP, but without difference $(p<0.05)$ when compared to the control treatment with mineral $N$. Concerning LPP the strain INPA 03-11B was similar to strain UFLA 03-84 and the control treatment with mineral $\mathrm{N}$ mineral, both were superior to the control treatment without any N source. Both MPP and M100G were benefited by the strain INPA 03-11B, which was more efficient than the other treatments (Table 5).

The inoculation with bacterial strains influenced positively the production variables evaluated, contributing to an increase in LPP, MPP and M100G, demonstrating the efficiency of strains to provide nitrogen and promote growth. In field conditions, Almeida et al. (2010), observed higher values of NPP, LPP and MPP. This fact is related with cultivation in pots, which reduced the production potential of cowpea.

Table 5. Production of cowpea (Vigna unguiculata L. Walp) cultivar EPACE 10, inoculated with rhizobia strains.

\begin{tabular}{lllll}
\hline \multirow{2}{*}{ Nitrogen sources } & NPP & LPP & MPP & M100G \\
\cline { 2 - 5 } & plant $^{-1}$ & cm plant $^{-1}$ & $-1 .----$ p plant $^{-1}-----$ & \\
\hline INPA 03-11B & $7.81^{\mathrm{a}}$ & $13.19^{\mathrm{ab}}$ & $3.28^{\mathrm{a}}$ & $25.23^{\mathrm{a}}$ \\
UFLA 3-84 & $6.69^{\mathrm{b}}$ & $12.55^{\mathrm{ab}}$ & $2.36^{\mathrm{b}}$ & $21.36^{\mathrm{b}}$ \\
With N & $6.91^{\mathrm{ab}}$ & $13.65^{\mathrm{a}}$ & $2.58^{\mathrm{b}}$ & $19.8^{\mathrm{bc}}$ \\
Without N & $4.51^{\mathrm{c}}$ & $11.43^{\mathrm{b}}$ & $1.31^{\mathrm{c}}$ & $19.52^{\mathrm{c}}$ \\
CV (\%) & 12.40 & 17.08 & 15.94 & 7.61 \\
\hline
\end{tabular}

*Means followed by the same letter within the column are not statistically different by the Tukey test at $5 \%$ probability. With $\mathrm{N}=$ $70 \mathrm{~kg} \mathrm{ha}^{-1}$ of mineral $\mathrm{N}$, Without $\mathrm{N}=$ without inoculation and without $\mathrm{N}$ fertilization. NPP, LPP and MPP= number, length and matter of pod per plant, $\mathrm{M} 100 \mathrm{G}=$ matter of 100 grains.

Analogous to the results obtained in the vegetative growth stage, inoculation with strains INPA 03$11 \mathrm{~B}$ and UFLA 03-84 showed better results for the reproductive stage of cowpea plants. The increment of values in the production variables on inoculated treatments demonstrates the efficiency of these strains to supply the required $\mathrm{N}$ and promote vegetal growth. The results obtained in the present work agree with results obtained after inoculating these strains in experiments performed in different soil and climatic conditions by Costa et al. (2016), Lira Júnior et al. (2017), Marinho et al. (2017), Batista et al. (2017) and Xavier et al. (2017).

A significant correlation was observed $(p<0.01)$ between CLT and CLA and CLB (Table 6). Chlorophyll is related with the plant photosynthetic activity and therefore the quantities of these pigments reflect the nutritional stage of cowpea, demonstrating that, the most efficient the BNF, the higher the chlorophyll indices will be and, consequently, higher DMAP will happen. Thus, with the deficiency or absence of nitrogen a reduction in both variables will occur. 
Table 6. Estimative of correlation coefficients of Spearman, with their respective significances between 18 growth and production variables for cowpea (Vigna unguiculata L. Walp), cultivar EPACE 10, inoculated with diazotrophic bacteria and submitted to different light environments.

\begin{tabular}{|c|c|c|c|c|c|c|c|c|c|c|}
\hline Variables & CLA & CLB & CLT & DMAP & DMR & DMT & RE & GNAP & NN & DMN \\
\hline CLB & $0.82^{\text {ns }}$ & & & & & & & & & \\
\hline CLT & $0.97^{* *}$ & $0.94^{* *}$ & & & & & & & & \\
\hline DMAP & $0.01^{\mathrm{ns}}$ & $0.07^{\mathrm{ns}}$ & $0.04^{\mathrm{ns}}$ & & & & & & & \\
\hline DMR & $-0.03^{n s}$ & $-0.02^{\mathrm{ns}}$ & $-0.03^{\text {ns }}$ & $0.67^{* *}$ & & & & & & \\
\hline DMT & $0.00^{\mathrm{ns}}$ & $0.06^{\mathrm{ns}}$ & $0.03^{\text {ns }}$ & $0.99^{* *}$ & $0.75^{* *}$ & & & & & \\
\hline $\mathrm{RE}$ & $-0.08^{n s}$ & $-0.10^{\text {ns }}$ & $-0.09^{n s}$ & $0.65^{* *}$ & $0.68^{* *}$ & $0.68^{* *}$ & & & & \\
\hline GNAP & $-0.01^{\mathrm{ns}}$ & $0.05^{\mathrm{ns}}$ & $0.02^{\mathrm{ns}}$ & $0.95^{* *}$ & $0.81^{* *}$ & $0.97^{* *}$ & $0.67^{* *}$ & & & \\
\hline NN & $-0.21^{\mathrm{ns}}$ & $-0.04^{\mathrm{ns}}$ & $-0.15^{\mathrm{ns}}$ & $0.69^{* *}$ & $0.63^{* *}$ & $0.71^{* *}$ & $0.36^{\mathrm{ns}}$ & $0.68^{* *}$ & & \\
\hline DMN & $-0.08^{\text {ns }}$ & $-0.11^{\mathrm{ns}}$ & $-0.10^{\text {ns }}$ & $0.47^{\text {ns }}$ & $0.60^{\text {ns }}$ & $0.51^{\text {ns }}$ & $0.43^{\text {ns }}$ & $0.45^{\mathrm{ns}}$ & $0.57^{\text {ns }}$ & \\
\hline M100G & $0.09^{n s}$ & $0.17^{\mathrm{ns}}$ & $0.13^{\mathrm{ns}}$ & $0.63^{*}$ & $0.68^{* *}$ & $0.66^{\mathrm{ns}}$ & $0.48^{\text {ns }}$ & $0.62^{\mathrm{ns}}$ & $0.63^{*}$ & $0.58^{\text {ns }}$ \\
\hline
\end{tabular}

ns non-significant; ${ }^{*}$ significant at $5 \%$ probability $(p<0.05)$; and ${ }^{* *}$ significant at $1 \%$ probability $(p<0.01)$, by the $t$ test. CLA, CLB and $\mathrm{CLT}=$ indices of chlorophyll $a, b$ and total; DMAP, DMR and DMT = dry matter of the aerial portion, the roots and total dry matter; $\mathrm{RE}=$ relative efficiency; GNAP= gathering of nitrogen in the aerial portion; $N N$ and $\mathrm{DMN}=$ number and dry matter of nodules; $\mathrm{M} 100 \mathrm{G}=$ matter of 100 grains.

Among the analyzed variables, DMAP, DMR, DMT and GNAP had a correlation with NN, evidencing the efficiency of BNF for cowpea growth (Table 6). Nitrogen fixing bacteria and light environments under Aluminet and full sun promoted increments in vegetative growth and production components in cowpea.

Light environments under Aluminet and full sun were the best environments for cowpea cultivation and the strain INPA 03-11B maximizes growth and production components in cowpea, reducing the demand for nitrogen fertilization. However, as cowpea cultivated under Aluminet showed similar results to full sun treatment, the cultivation of cowpea may be recommended under thermo-converting Aluminet nets or under full sun.

\section{Conclusions}

The strain INPA 03-11B can promote higher nodulation in cowpea plants under Aluminet and full sun environments. The strain UFLA 03-84 has efficient nodulation only when cultivated in full sun environment. The efficiency of diazotrophic bacteria to promote vegetative growth, nitrogen nutrition and production is not affected by different light environments. Therefore, the cultivation of cowpea is recommended to be accomplished in full sun environment, independently form the nitrogen sources used.

Authors' Contributions: CORREIA, A.J.: conception and design, acquisition of data, analysis and interpretation of data and drafting the article; NÓBREGA, R.S.A.: conception and design, and critical review of important intellectual content; OLIVEIRA, A.S.: acquisition of data; SANTANA, W.S.: acquisition of data; BRAULIO, C.S.: acquisition of data; OLIVEIRA, M.S.: acquisition of data; SOUSA, C.B.C.: acquisition of data; SANTOS, A.R.: conception and design, and critical review of important intellectual content. All authors have read and approved the final version of the manuscript.

Conflicts of Interest: The authors declare no conflicts of interest.

Ethics Approval: Not applicable.

Acknowledgments: The authors would like to thank the funding for the realization of this study provided by the Brazilian agency CAPES (Coordenação de Aperfeiçoamento de Pessoal de Nível Superior - Brasil), Finance Code 001.

\section{References}

ALMEIDA, A.L.G., et al. Produtividade do feijão-caupi cv BR 17 Gurguéia inoculado com bactérias diazotróficas simbióticas no Piauí. Revista Brasileira de Ciências Agrárias. 2010, 5(3), 364-36. http://dx.doi.org/10.5039/agraria.v5i3a795

ALVES, A.C., et al. Biomass production and essential oil of lemon balm cultivated under colored screens and nitrogen. Horticultura Brasileira. 2018, 36(1), 94-99. https://doi.org/10.1590/S0102-053620180116

ANDRADE JÚNIOR, A.S., et al. Q. Cultivo do Feijão-caupi (Vigna unguiculata L. Walp.). 1ạ ed. Teresina: Embrapa Meio-Norte, 2002. 
ARRUDA, J.S., LOPES, N.F. and BACARIN, M.A. Nodulação e fixação do dinitrogênio em soja tratada com sulfentrazone. Pesquisa Agropecuária Brasileira. 2001, 36(2), 325-330. http://dx.doi.org/10.1590/S0100-204X2001000200016

BATISTA, É.R., et al. Combined inoculation of rhizobia on the cowpea development in the soil of Cerrado. Revista Ciência Agronômica. 2017, 48(5 Especial), 745-755. https://doi.org/10.5935/1806-6690.20170087

COSTA, E.M., et al. Bacterial strains from floodplain soils perform different plant-growth promoting processes and enhance cowpea growth. Scientia Agrícola. 2016, 73(4), 301-310. https://doi.org/10.1590/0103-9016-2015-0294

COSTA, E.M., et al. Classification of the inoculant strain of cowpea UFLA 03-84 and of other strains from soils of the Amazon region as Bradyrhizobium viridifuturi (symbiovar tropici). Brazilian Journal of Microbiology. 2019, 50(18). https://doi.org/10.1007/s42770-019-00045-x

COSTA, E.M., et al. Crescimento e produtividade de feijão-caupi cultivar BRS Guariba inoculado com estirpes de rizóbio no sudoeste do Piauí. Semina: Ciências Agrárias. 2014, 35(6), 3073-3084. https://doi.org/10.5433/1679-0359.2014v35n6p3073

FARIAS, T.P., et al. Symbiotic efficiency of rhizobia strains with cowpea in southern Maranhão. Revista Caatinga. 2016a, 29(3), 611-618. http://dx.doi.org/10.1590/1983-21252016v29n311rc

FARIAS, T.P., et al. Rhizobia inoculation and liming increase cowpea productivity in Maranhão State. Acta Scientiarum. 2016b, 38(3), 387-395. https://doi.org/10.4025/actasciagron.v38i3.28630

FROTA, K. de M.G., SOARES, R.A.M., and ARÊAS, J.A. Composição química do feijão caupi (Vigna unguiculata L. Walp), cultivar BRS-Milênio. Ciência e Tecnologia de Alimentos. 2008, 28(2), 470-476. https://doi.org/10.1590/S0101-20612008000200031

GOPALAKRISHNAN, S., et al. Plant growth promoting rhizobia: challenges and opportunities. 3 Biotech. 2015, 5(4), 355-377. https://doi.org/10.1007/s13205-014-0241-x

HELDWEIN, A.B., et al. Plastocrono e rendimento de feijão-de-vagem cultivado sob ambiente protegido e no ambiente externo em semeadura tardia no outono. Ciência Rural. 2010, 40(4), 768-773. http://dx.doi.org/10.1590/S0103-84782010005000045

HENRIQUE, P. de C., et al. Aspectos fisiológicos do desenvolvimento de mudas de café cultivadas sob telas de diferentes colorações. Pesquisa Agropecuária Brasileira. 2011, 46(5), 458-465. http://dx.doi.org/10.1590/s0100-204×2011000500002

HIRATA, A.C.S. and HIRATA, E.K. Desempenho produtivo do agrião d'água cultivado em solo sob telas de sombreamento. Pesquisa Agropecuária Brasileira. 2015, 50(10), 895-901. http://dx.doi.org/10.1590/50100-204X2015001000005

ILIC, Z.S., et al. Effects of the modification of light intensity by color shade nets on yield and quality of tomato fruits. Scientia Horticulturae. 2012, 139, 90-95. https://doi.org/10.1016/j.scienta.2012.03.009

KERBAUY, G.B. Fisiologia Vegetal. 3a ed. Rio de Janeiro: Editora Guanabara Koogan S.A., 2019.

LACERDA, C.F. de, et al. Análise de crescimento de milho e feijão sob diferentes condições de sombreamento. Revista Brasileira de Ciências Agrárias. 2010, 5(1), 18-24. http://dx.doi.org/10.5039/agraria.v5i1a485

LIMA, J.D., et al. Variáveis fisiológicas de antúrio cultivado sob diferentes malhas de sombreamento. Scientia Agrária. 2010, 11(3), $193-200$. http://dx.doi.org/10.5380/rsa.v11i3.17232

LIRA JÚNIOR, M.A.L., et al. Rhizobial diversity for tropical pulses and forage and tree legumes in Brazil. In: Zaidi, A.; Khan, M.S.; Musarrat, J. (Org.). Microbes for legumes improvement. Springer. 2017, pp. 135-151.

MAPA (Ministério da Agricultura Pecuária e Abastecimento). Normas sobre especificações, garantias, registro, embalagem e rotulagem dos inoculantes destinados à agricultura, Instrução Normativa $n^{\circ}$ 13, Brasil, 2011. [consulted on 2019-03-05]. Available from Internet: http://www.ctpconsultoria.com.br/pdf/Instrucao-Normativa-13-de-24-03-2011.pdf

MARINHO, R. de C.N., et al. Symbiotic and agronomic efficiency of new cowpea rhizobia from Brazilian Semi-Arid. Bragantia. 2017, 76(2), 273281. http://dx.doi.org/10.1590/1678-4499.003

MATHEWS, S. Evolutionary studies illuminate the structural-functional model of plant phytochromes. The Plant Cell. 2010, 22, 4-16. https://doi.org/10.1105/tpc.109.072280

PAULUS, D., et al. Biomassa e composição do óleo essencial de manjericão cultivado sob malhas fotoconversoras e colhido em diferentes épocas. Horticultura Brasileira. 2016, 34(1), 46-53. http://dx.doi.org/10.1590/S0102-053620160000100007.

POLYSACK INDÚSTRIAS Ltda, 2020. Aluminet I [online]. [Accessed on 2019-05-15]. Available from Internet: http://www.polysack.com.br R DEVELOPMENT CORE TEAM. R: A language and environment for statistical computing. R Foundation for Statistical Computing Vienna, 2018. [Accessed on 2019-04-14]. Available from Internet: http://www.r-project.org

SANTOS, E.R. dos, et al. Crescimento e teores de pigmentos foliares em feijão-caupi cultivado sob dois ambientes de luminosidade. Revista Caatinga. 2011, 24(4), 14 -19.

SOUZA, G.S. de, et al. Crescimento vegetativo e produção de óleo essencial de plantas de alecrim cultivadas sob telas coloridas. Bioscience Journal. 2014, 30(3), 232-239.

SOUZA, J.R.P., et al. Produção e textura de feijão-vagem cultivado sob diferentes níveis de sombreamento. Horticultura Brasileira. 2001, 19(3), 247-249. https://doi.org/10.1590/S0102-05362001000300020 
TAIZ, L. and ZEIGER, E. Fisiologia vegetal. $5^{\text {th }}$ ed. Porto Alegre: Artmed, 2013.

WEATHERBURN, M.W. Phenol-hypochlorite reaction for determination of ammonia. Analytical Chemistry. 1967, 39(8), 971-974. https://doi.org/10.1021/ac60252a045

XAVIER, G.R., et al. Agronomic effectiveness of rhizobia strains on cowpea in two consecutive years. Australian Journal of Crop Science. 2017, 11(9), 1154-1160. https://doi.org/10.21475/ajcs.17.11.09.pne715

Received: 14 November 2019 | Accepted: 27 September 2020 | Published: 13 October 2021

This is an Open Access article distributed under the terms of the Creative Commons Attribution License, which permits unrestricted use, distribution, and reproduction in any medium, provided the original work is properly cited. 